\title{
Nutritional Management of the Critically III Obese Patient
}

\author{
Mohd Basri Mat-Nor ${ }^{\mathrm{a}}$, Noor Airini Ibrahim ${ }^{\mathrm{b}}$, Fa'iza Abdullah ${ }^{\mathrm{c}}$
}

${ }^{a}$ Department of Anaesthesiology and Intensive Care, Kulliyyah of Medicine, International Islamic University Malaysia, Kuantan, Pahang.

${ }^{b}$ Anaesthesiology Unit, Department of Surgery, Faculty of Medicine and Health Sciences, Universiti Putra Malaysia, 43400 Serdang, Selangor, Malaysia

'Department of Family Medicine, Kulliyyah of Medicine, International Islamic University Malaysia, Kuantan, Pahang

\section{INTRODUCTION}

Over the last decade, Malaysia has witnessed a steady rise in obesity rate. The overweight and obese now comprise of half its 30 million population. This figure is broken down into 30 percent in the overweight category and 17.7 percent in the obese category, according to the 2015 National Health and Morbidity Survey. ${ }^{1}$ This is an increase of four times from what was reported in 1996, at 4.4 percent. $^{2}$ World Health Organization (WHO) definition of obesity is body mass index (BMI) of 30 or more, calculated as weight in kilograms divided by height in metres squared. ${ }^{3}$ As the general population get heavier, the average BMI of ICU admissions have also increased. From the International Nutrition Survey (INS) 2014, the average BMI of critically ill patients admitted to Serdang Hospital was $26 \mathrm{~kg} / \mathrm{m}^{2}$ higher than the Asian average at $23.6 \mathrm{~kg} / \mathrm{m}^{2}{ }^{4}$ Being obese puts the patients at a greater risk of heart disease, hypertension, stroke, diabetes, sleep apnoea, fatty liver disease, osteoarthritis, and many other serious medical conditions.

In critically obese patients, timely initiation of appropriate nutrition is key to their management, and to achieve this it is essential that accurate

Corresponding author :

Dr. Mohd Basri Mat Nor,

Department of Anaesthesiology and Intensive Care, Kulliyyah of Medicine,

International Islamic University Malaysia,

Indera Mahkota Campus, 25200 Kuantan, Pahang

Tel: $+609-5911870$

Fax: $+609-5716759$

Email: m.basri@iium.edu.my assessment of their nutritional needs is carried out early on in their intensive care stay. Large variations in body composition among the obese coupled with lack of reliable predictive equations make estimation of caloric requirements extremely challenging. Furthermore, in times of stress, protein-energy malnutrition occurs more readily and goes undetected more frequently in obese patients compared to their non-obese counterparts. Negative caloric balance in the critically ill obese patients puts them at higher risk for delayed wound healing, secondary infections, prolonged hospital stay and death.

\section{GENERAL CONSIDERATIONS}

Provision of nutrition therapy in critically ill obese patients requires special knowledge due to the complexity of their conditions. Altered anatomy, physiology, and pharmacokinetics in obesity may contribute to mechanical difficulties in assessing, monitoring, and performing procedures that are related to nutritional management. The associated comorbidities may further put them at higher risk of complications than their lean counterparts. ${ }^{5}$ Misconceptions associated with obesity, such as they have increased nutrient reserves, should be avoided. Nutrition therapy should be commenced as early as feasible within 24-48 hours after stabilisation. They are prone to develop protein malnutrition due to the presence of elevated basal insulin levels that facilitate protein breakdown to glucose via inhibition of lipid mobilisation. ${ }^{6}$ The accelerated protein breakdown to match energy requirements may result in uncontrolled lean body mass depletion giving rise to sarcopenic obesity. 
In critically ill obese patients, appropriate balance of caloric and nutritional support continues to be a clinical challenge. Underfeeding and overfeeding may give rise to unwanted medical sequelae. For example, overfeeding may result in fluid overload, hyperglycaemia, poor blood glucose control, hepatic steatosis, increased carbon dioxide production, increased ventilator demand, and prolonged mechanical ventilation.

\section{BODY COMPOSITION AND METABOLIC RATE}

Generally, obese ICU patients show greater tendency towards metabolic derangements, especially involving the peripheral use of fuel. In response to critical illness, they are at greater risk for insulin resistance, impaired fat oxidative metabolism, and accelerated protein degradation. Jeevanandam et al. showed significant differences in the use of endogenous fuel supplies between starved obese trauma patients and their non-obese counterparts, where only $39 \%$ of their resting energy expenditure (REE) were derived from fat metabolism, compared with $61 \%$ in the latter. $^{7}$ Hypocaloric, high-protein nutrition therapy is preferred as it enhances endogenous lipid oxidation while avoiding use of fat free mass (FFM) ${ }^{8}$ It is also important to avoid overfeeding as increased caloric load will enhance protein turnover and fat storage. Stress-induced hyperglycaemia is common sequelae in the diabetic or non-diabetic critically ill, and results in worse outcomes. ${ }^{9}$ As insulin resistance and diabetes is more prevalent among the obese, it is therefore imperative to incorporate glycaemic control in the nutrition plan. Insulin infusion is the preferable method, as insulin absorption may vary if given subcutaneously due to substantial amounts of adipose tissue. ${ }^{10}$

\section{NUTRITION ASSESSMENT}

Prior to initiation of feeding, a focused assessment will help determine nutritional risks and concurrent comorbidities that may influence choice of nutritional targets, route and formulation. As for lean counterparts, nutritional risk screening should be done (e.g. modified NUTRIC score) to identify patients with higher nutritional risk that may benefit from early aggressive nutritional interventions. ${ }^{11,12}$ Various parameters like anthropometric measures (actual body weight $[A B W]$, ideal body weight [IBW], height, and waist circumference) and metabolic markers (serum triglyceride, cholesterol, and glucose) should be included in the initial assessment. Body mass index (BMI) is then calculated and class of obesity is identified. Adjusted body weight is not recommended since it has variable definitions and overestimates caloric needs, as fat tissue is metabolically less active than FFM. In addition, there is not enough validation data to support its reliability in ICU patients. ${ }^{13}$

Obese ICU patients should be evaluated for type of fat distribution, evidence of sarcopenia, metabolic syndrome, actual BMI and presence of systemic inflammatory response syndrome (SIRS). Assessment of obesity-related comorbidities, such as diabetes, congestive cardiac failure, hypertension, obstructive sleep apnoea, and fatty liver disease, should also be done. Risk stratification is done according to extent of comorbidities and degree of functional limitations. These factors may put them at highest risk and increase the complexity of nutrition provision; therefore, measures should be taken to avoid potential complications.

In obese ICU patients, the presence of malnutrition is always underestimated. One prospective study demonstrated than in patients with BMI more than $25,57 \%$ were malnourished. ${ }^{14}$ Another study showed pre-existing obesity is associated with greater risk of malnutrition from delay in physician initiation of nutritional therapy. ${ }^{15}$ It is important to acknowledge that malnourished critically ill obese patients have worse outcomes as compared to those without malnutrition. ${ }^{16}$ The mortality curve when plotted against $\mathrm{BMI}$ forms a $\mathrm{U}$-shape with the highest rate being in the morbidly obese (BMl>40) and in the low BMI group (<25). Morbidity and mortality are lowest in ICU patients with BMI between 30 and 40 (class I and II obesity). This survival advantage of mildmoderate obesity during critical illness is known as the obesity paradox. ${ }^{17}$ This leads to the misconception that early feeding is not as beneficial in these groups of critically ill patients.

\section{ENERGY REQUIREMENT}

Upon initiation of nutritional therapy, energy and protein requirements are determined to set nutritional targets and how fast they need to be achieved. In a recent study, determination of which patients were most likely to benefit from nutritional 
therapy depends on their nutritional risk and adequacy of energy provision. ${ }^{18}$ Singer et al. demonstrated that providing nutritional therapy guided by measurements of REE using indirect calorimetry (IC) in ICU patients was achievable and may be associated with lower hospital mortality. ${ }^{19}$ Calculating energy requirement accurately is extremely difficult among the obese due to large variations in their body composition. The published predictive equations for predicting energy expenditure (EE) of the obese ICU population have been shown to be inaccurate. No equation has been found to be most suitable in the obese, leading to the current recommendation to perform indirect IC, when available, for determination of their energy requirements. ${ }^{20}$

For all classes of obesity, the daily caloric goal should be within $65 \%-75 \%$ of target energy requirements calculated by IC. However, when IC is unavailable, the current recommendation is to use simplistic weight-based equations that may estimate this goal using $11-14 \mathrm{kcal} / \mathrm{kg} \mathrm{ABW} /$ day for $\mathrm{BMI}$ of $30-50$ and $22-25 \mathrm{kcal} / \mathrm{kg} \mathrm{IBW} /$ day for $\mathrm{BMI}>$ 50. Evaluation of these two equation found that, accuracy was significantly improved if used according to the category of obesity as suggested. Protein requirements are also not easy to ascertain and may be determined by a weight-based simplistic equation of $2.0 \mathrm{~g} / \mathrm{kg} \mathrm{IBW/day} \mathrm{(for} \mathrm{classes}$

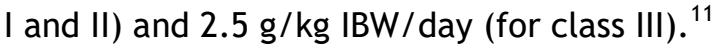

\section{HYPOCALORIC, HIGH-PROTEIN NUTRITION THERAPY}

Hypocaloric feeding refers to the provision of caloric intake that is less than the calculated energy requirement whereas eucaloric feeding is to provide enough energy to meet caloric requirements. While hypocaloric feeding is able to accommodate protein and calorie deficits, hypocaloric, high protein nutrition is meant to create a caloric deficit while sufficient protein supply is ensured. This should be the strategy employed to the critically ill obese patients whether it is provided through enteral or parenteral route. ${ }^{8,13}$ Obese patients are more susceptible to develop sarcopenia as a result of body response to critical illness. This feeding regimen has emerged as a recent strategy capable of preventing metabolic complications of overfeeding, preserving lean body mass while promoting steady weight loss. This strategy enhances oxidation of endogenous fat and thus reduces the utilisation of FFM and induces favourable changes in body composition. About 15 years ago, Dickerson and colleagues showed improved outcomes with the hypocaloric high protein strategy as compared to the eucaloric high protein approach in critically obese patients. Furthermore, for the first time they were able to demonstrate that it was possible to successfully achieve this therapy by enteral route. ${ }^{21}$ This approach has been shown among critically ill obese patients to increase positive nitrogen balance and improve clinical outcomes without adding any deleterious side effects as compared to high-protein, eucaloric feeding. ${ }^{21-24}$ Recent data have shown lesser complications, reduced length of hospital stay and improved 60-day mortality.

Table I below summarises the studies evaluating the clinical outcomes of this feeding strategy. On the other hand, low protein in combination with a hypocaloric feeding is associated with unfavourable outcomes. ${ }^{25}$ Elderly obese patients are comparable to younger counterparts in achieving nitrogen balance using this feeding regimen. However, they are at higher risk for developing azotemia, thus close monitoring is warranted. ${ }^{26}$ There are contraindications to the use of high protein (e.g. evolving acute renal failure or hepatic encephalopathy) but relatively few conditions preclude hypocaloric feeding. In some patients full caloric loads may be preferred e.g. recurrent hypoglycaemia or severe immunocompromised state.

There is a need for the development of unique enteral formulation specifically for the critically obese patient. Normally, the ratio of non-protein calories to nitrogen ratio (NPC:N) is around 150:1. Most of the standard EN formulas have high NPC:N, which requires addition of protein, usually in modular form to achieve a protein goal of $2 \cdot 0-2.5 \mathrm{~g} /$ $\mathrm{kg}$ IBW. The ideal enteral formula should have a low $\mathrm{NPC}: \mathrm{N}$, the current feeding regimen suggests a ratio of approximately 40-50:1. Enteral feeding with standard caloric density of $1.0 \mathrm{kcal} / \mathrm{mL}$ is suitable to meet the often higher volume requirement. ${ }^{13}$ The more appropriate protein source may be whey protein with both protein and fat making up no more than 15 to $20 \%$ of calories. In theory, immune modulating formulas may provide potential benefit by reducing inflammation in obese ICU patients. ${ }^{27}$ However, to date, there is inadequate data to recommend their utilisation. 
Table I. Previous studies with hypocaloric, high protein nutrition therapy for acutely ill patients with obesity.

\begin{tabular}{|c|c|c|c|c|c|}
\hline & Authors, Objectives & $\begin{array}{l}\text { N, Population, } \\
\text { Setting }\end{array}$ & Design, Quality & Outcomes & Conclusion \\
\hline 1. & $\begin{array}{l}\text { Dickerson RN, Rosato } \\
\text { EF, Mullen } \mathrm{JL}^{22} \\
\text { Am J Clin Nutr } \\
1986 \\
\text { - Evaluate efficacy of } \\
\text { HCHP feeding }\end{array}$ & $\begin{array}{l}-\mathrm{N}=13 \\
\text {-Acutely ill post- } \\
\text { operative obese } \\
\text { patients } \\
\text {-Majority with } \\
\text { anastomotic leak } \\
\text { from gastric bypass } \\
\text { surgery }\end{array}$ & $\begin{array}{l}\text {-Prospective, Case } \\
\text { series, } \\
\text {-TPN } \\
\text {-Hypocaloric: NPC of } \\
\sim 50 \% \text { of measured REE } \\
\text { - Protein }(2.1 \mathrm{~g} / \mathrm{kg} \\
\text { IBW } / \text { day } \\
\text {-Total energy } 70 \% \\
\text { measured REE } \\
\text {-Duration of NT: } 48 \pm \\
31 \text { days } \\
\text {-Small sample }\end{array}$ & $\begin{array}{l}\text {-Outcome was } \\
\text { measured on NB, } \\
\text { wound \& fistula } \\
\text { healing } \\
\text {-Positive NB in } \\
\text { eight pts, closure of } \\
\text { fistulas and } \\
\text { complete tissue } \\
\text { healing }\end{array}$ & $\begin{array}{l}\text { Authors concluded that } \\
\text { HCHP nutrition therapy } \\
\text { is associated with } \\
\text { nitrogen equilibrium } \\
\text { and good clinical } \\
\text { outcomes }\end{array}$ \\
\hline 2. & $\begin{array}{l}\text { Burge JC, Goon A, } \\
\text { Choban PS, et al. } \\
\text { JPEN } 1994 \\
\text {-Evaluate impact of } \\
\text { hypocaloric PN on } \\
\text { nitrogen balance }\end{array}$ & $\begin{array}{l}\mathrm{N}=16 \\
- \text { Hypocaloric, } N=9 \\
\text {-Eucaloric, } N=7 \\
\text {-Critically ill obese } \\
(>130 \% \text { IBW) }\end{array}$ & $\begin{array}{l}\text {-RCT, } \\
\text {-TPN } \\
\text {-Hypocaloric ( } 50 \% \text { REE } \\
\text { of NPC) vs -vs eucalor- } \\
\text { ic ( } 100 \% \text { of REE) } \\
\text {-Isonitrogenous ( } 2 \mathrm{~g} / \mathrm{kg} \\
\text { IBW/day) } \\
\text {-Duration of NT: } 8.6 \pm \\
3 \text { days } \\
\text {-Small sample }\end{array}$ & $\begin{array}{l}\text {-No significant } \\
\text { difference NB }\end{array}$ & $\begin{array}{l}\text { Hypocaloric feedings } \\
\text { can be effectively given } \\
\text { to critically ill obese } \\
\text { patients and can } \\
\text { achieve comparable } \\
\text { nitrogen balance }\end{array}$ \\
\hline 3. & $\begin{array}{l}\text { Choban PS, Burge JC, } \\
\text { Scales D, et al. }{ }^{24} \\
\text { Am J Clin Nutr } 1997 \\
\text {-Evaluate efficacy of } \\
\text { HC vs. EC PN with } \\
\text { protein } 2 \mathrm{~g} / \mathrm{kg} \text { IBW/d }\end{array}$ & $\begin{array}{l}\mathrm{N}=30 \\
- \text { Hypocaloric, } \mathrm{N}=6 \\
\text {-Eucaloric, } \mathrm{N}=14 \\
\\
\text {-Obese surgical } \\
\text { patients with } \mathrm{BMI}> \\
35 \text { in both ICU (50\%) } \\
\text { and general wards. }\end{array}$ & $\begin{array}{l}-\mathrm{RCT}, \\
\text {-TPN } \\
\text {-EE not measured, } \\
\text { weight based } \\
\text {-Hypocaloric (14 kcal/ } \\
\mathrm{kg} \mathrm{ABW/day)} \\
\text { - vs Eucaloric (22 } \pm 5 \\
\mathrm{kcal} / \mathrm{kgABW} / \text { day) } \\
\text { - Isonitrogenous at } 2 \mathrm{~g} / \\
\mathrm{kg} \text { IBW/day } \\
\text {-Duration of NT: } 10 \pm \\
\text { 2.6 days } \\
\text {-Small sample }\end{array}$ & $\begin{array}{l}\text {-No difference in } \\
\text { net NB, length of } \\
\text { hospital stay, or } \\
\text { mortality } \\
\text {-No significant } \\
\text { weight change } \\
\text {-Eucaloric regimen- } \\
\text { required more insu- } \\
\text { lin for a greater } \\
\text { number of days }\end{array}$ & $\begin{array}{l}\text { Comparable NB can be } \\
\text { observed in hospitalised } \\
\text { obese patients receiving } \\
\text { hypoenergetic } \\
\text { compared to } \\
\text { normoenergetic PN }\end{array}$ \\
\hline 4. & $\begin{array}{l}\text { Dickerson RN, } \\
\text { Boschert KJ, Kudsk } \\
\text { KA, et al. }{ }^{21} \\
\text { Nutrition } 2002 \\
\text {-Evaluate nutrition } \\
\text { and clinical efficacy } \\
\text { of eucaloric vs hy- } \\
\text { pocaloric EN }\end{array}$ & $\begin{array}{l}\mathrm{N}=40 \\
\text {-Critically ill obese } \\
\text { trauma patients } \\
- \text { Minimal } 7 \text { days on } \\
\text { EN } \\
\text {-Baseline BMI } 41.3 \pm \\
4.7\end{array}$ & $\begin{array}{l}\text {-Retrospective, } \\
\text {-Enteral Nutrition } \\
\text { - Eucaloric (19 kcal/kg } \\
\text { ABW/day) } \\
\text { - vs Hypocaloric (11 } \\
\text { kcal/kg ABW/day). } \\
\text {-Both group } 2 \mathrm{~g} / \mathrm{kg} \\
\text { IBW protein } \\
\text {-Small sample }\end{array}$ & $\begin{array}{l}\text {-No difference NB } \\
\text {-In HC group: de- } \\
\text { crease in length of } \\
\text { ICU stay, decreased } \\
\text { antibiotic days, and } \\
\text { a trending decrease } \\
\text { in ventilator days. }\end{array}$ & $\begin{array}{l}\text { Hypocaloric EN is at } \\
\text { least as effective as } \\
\text { eucaloric feeding } \\
{ }^{*} \text { First study to } \\
\text { demonstrate improved } \\
\text { clinical outcomes with } \\
\text { HCHP nutrition therapy } \\
\text { in critically ill obese } \\
\text { patients. } \\
\text { *First study } \\
\text { implementing this } \\
\text { therapy by EN }\end{array}$ \\
\hline 5. & $\begin{array}{l}\text { Dickerson RN, Medling } \\
\text { TL, Smith AC, et al. }{ }^{26} \\
\text { JPEN J Parenter } \\
\text { Enteral Nutr } 2013 \\
\text {-Examine whether } \\
\text { older, obese critically } \\
\text { ill trauma patients } \\
\text { achieve nitrogen } \\
\text { equilibrium and } \\
\text { obtain similar clinical } \\
\text { outcomes to younger } \\
\text { patients during HCHP } \\
\text { therapy }\end{array}$ & $\begin{array}{l}\mathrm{N}=74 \\
\text {-Admission to trau- } \\
\text { ma centre } \\
\text {-BMl } 35 \pm 6 \mathrm{~kg} / \mathrm{m}^{2} \\
\text {-Age } 18-59 \text { yo, } \mathrm{N}= \\
41 \\
\text {-vs Age }>60 \text { yo, } \mathrm{N}= \\
33\end{array}$ & $\begin{array}{l}\text {-Retrospective, cohort } \\
\text { observation, } \\
\text {-EN (81\%) or PN (then } \\
\text { transitioned to EN) } \\
\text {-Younger: } 18 \mathrm{kcal} / \mathrm{kg} \\
\text { IBW, protein } 1.9 \mathrm{~g} / \mathrm{kg} \\
\text { IBW/day } \\
\text {-Older: } 21 \mathrm{kcal} / \mathrm{kg} \\
\text { IBW, protein } 2.1 \mathrm{~g} / \mathrm{kg} \\
\text { IBW/day }\end{array}$ & $\begin{array}{l}\text {-Similar NB in both } \\
\text { groups } \\
\text {-Older patients } \\
\text { experienced } \\
\text { greater mean } \\
\text { serum urea } \\
\text { nitrogen } \\
\text { concentration but } \\
\text { none had renal } \\
\text { failure or } \\
\text { restriction of intake } \\
\text {-Similar clinical } \\
\text { outcomes }\end{array}$ & $\begin{array}{l}\text {-Older patients had an } \\
\text { NB equivalent to } \\
\text { younger patients when } \\
\text { given adequate protein } \\
\text { intake } \\
\text {-Older patients may be } \\
\text { at greater risk for } \\
\text { developing azotemia. }\end{array}$ \\
\hline
\end{tabular}

Legend: $\mathrm{RCT}$ = randomised controlled trial; $\mathrm{HCHP}=$ hypocaloric high protein; $\mathrm{NT}$ = nutrition therapy; NB = nitrogen balance; $\mathrm{ABW}$ = actual body weight; IBW = ideal body weight; $\mathrm{TPN}=$ total parenteral nutrition; $\mathrm{PN}=$ parenteral nutrition; $\mathrm{EN}$ = enteral nutrition; $\mathrm{BMI}$ = body mass index; $\mathrm{REE}$ = resting energy expenditure 


\section{MONITORING OF NUTRITION}

Patients should be monitored for nutritional adequacy, confirming adherence to the receipt of the prescribed feeding regimen. When available, the cumulative energy deficits need to be monitored by serial IC measurement to ensure and maintain energy provision within the $65 \%-75 \%$ of REE range. They should be monitored to avoid worsening hyperglycaemia, hyperlipidaemia, hypercapnoea, fluid overload, and hepatic fat accumulation. Therefore, frequent blood investigations, such as blood glucose level, arterial blood gases, serum triglyceride concentrations, serum electrolytes, and renal profiles, should be done. It is also important to record the intake/ output strictly to guarantee delivery of prescribed hypocaloric regimen and to detect any evidence of fluid overload.

\section{SUMMARY}

Critically obese patients are seen increasingly in our ICUs and pose specific challenges to intensivists. Presence of malnutrition is frequently underestimated and these patients need to be evaluated for type of fat distribution, evidence of sarcopenia, metabolic syndrome, actual BMI and presence of systemic inflammatory response syndrome (SIRS). Protein and caloric requirement predictions are frequently inaccurate. In the absence of IC, a recommended caloric intake of 11$14 \mathrm{kcal} / \mathrm{kg} \mathrm{ABW} /$ day for BMl of 30-50 and 22-25 $\mathrm{kcal} / \mathrm{kg} \mathrm{IBW} /$ day for $\mathrm{BMI}>50$ should be provided while protein requirements of $2.0 \mathrm{~g} / \mathrm{kg} \mathrm{IBW} /$ day (for classes I and II) and $2.5 \mathrm{~g} / \mathrm{kg}$ IBW/day (for class III) should be provided. Hypocaloric and high protein therapy has been shown in previous studies to provide better morbidity and mortality outcomes. Future studies should focus on finding a method to determine appropriate energy requirements and validate the benefits of a highprotein, hypocaloric feeding regimen in critically ill obese patients.

\section{REFERENCES}

1. Institute for Public Health (IPH) 2015. National Health and Morbidity Survey 2015 (NHMS 2015). Vol. II: Non-Communicable Diseases, Risk Factors \& Other Health Problems;2015.

2. Fatimah S, Tahir A, HN SS, Maimunah A. Nutritional Status of Adults Aged 18 Years and above. National Health and Morbidity Survey
1996, Volume 14. Institute of Public Health, Ministry of Health: Malaysia, 1999.

3. WHO Expert Committee on Physical status. WHO technical report series. Physical status: the use and interpretation of anthropometry. Report of a WHO Expert Committee; 854. 1995.

4. International Nutrition Survey 2014 (www.criticalcarenutrition.com) Site: GICU Hosp Serdang, Hospital Serdang, Malaysia.Assessed February 3, 2018.

5. Hogue CW, Stearns JD, Colantuoni E, et al. The impact of obesity on outcomes after critical illness: A meta-analysis. Intensive Care Med. 2009;35(7):1152-1170.

6. Abdul-Ghani MA, Muller FL, Liu Y, et al. Deleterious action of FA metabolites on ATP synthesis: possible link between lipotoxicity, mitochondrial dysfunction, and insulin resistance. Am J Physiol Endocrinol Metab. 2008;295(3):E678-85. doi:10.1152/ ajpendo.90287.2008.

7. Jeevanandam M, Young DH, Schiller WR. Obesity and the metabolic response to severe multiple trauma in man. J Clin Invest. 1991;87 (1):262-269.

8. Dickerson RN. Hypocaloric, High-Protein Nutrition Therapy for Critically III Patients With Obesity. Nutr Clin Pr. 2014;29(6):786-791.

9. van den Berghe $G$, Wouters $P$, Weekers $F$, et al. Intensive insulin therapy in critically ill patients. N Eng J Med. 2001;345(19):1359-1367.

10. Moghissi E, Korytkowski M, DiNardo M, et al. American Association of Clinical Endocrinologists and American Diabetes Association Consensus Statement on Inpatient Glycemic Control. Diabetes Care. 2009;32 (6):1119-1131.

11. Mcclave SA, Taylor BE, Martindale RG, Waren $M M$, Johnson DR. Guidelines for the Provision and Assessment of Nutrition Support Therapy in the Adult Critically III Patient: Society of Critical Care Medicine (SCCM) and American Society for Parenteral and Enteral Nutrition (A.S.P.E.N.). JPEN J Parenter Enter Nutr. 2016;40(2):159-211.

12. Rahman A, Hasan RM, Agarwala R, Martin C, Day $A G$, Heyland DK. Identifying critically-ill patients who will benefit most from nutritional therapy: Further validation of the "modified NUTRIC" nutritional risk assessment tool. Clin Nutr. 2016;35(1):158-162.

13. McClave SA, Kushner R, Van Way CW, et al. 
Nutrition Therapy of the Severely Obese, Critically Ill Patient: Summation of Conclusions and Recommendations. JPEN J Parenter Enter Nutr. 2011;35(5_suppl):88S-96S.

14. Kahokehr AA, Sammour T, Wang K, Sahakian V, Plank LD, Hill AG. Prevalence of malnutrition on admission to hospital - Acute and elective general surgical patients. ESPEN Eur E-J Clin Nutr Metab. 2010;5(1):e21-e25.

15. Pressoir M, Desne S, Berchery D, et al. Prevalence, risk factors and clinical implications of malnutrition in French Comprehensive Cancer Centres. Br J Cancer. 2011;102(6):966-971.

16. Robinson MK, Mogensen KM, Casey JD, et al. The Relationship Among Obesity, Nutritional Status, and Mortality in the Critically Ill*. Crit Care Med. 2015;43(1):87-100.

17. Akinnusi ME, Pineda LA, Solh AA El. Effect of obesity on intensive care morbidity and mortality: A meta-analysis. Crit Care Med. 2008;36(1):151-158.

18. Heyland DK, Dhaliwal R, Jiang X, Day AG. Identifying critically ill patients who benefit the most from nutrition therapy: the development and initial validation of a novel risk assessment tool. Crit Care. 2011;15(6):R268.

19. Singer $P$, Anbar R, Cohen J, et al. The tight calorie control study (TICACOS): a prospective, randomized, controlled pilot study of nutritional support in critically ill patients. Intensive Care Med. 2011;37(4):601-609.

20. McClave SA, Martindale RG, Kiraly L. The use of indirect calorimetry in the intensive care unit. Curr Opin Clin Nutr Metab Care. 2013;16(2):202208.

21. Dickerson RN, Boschert KJ, Kudsk KA, Brown RO. Hypocaloric enteral tube feeding in critically ill obese patients. Nutrition. 2002;18(3):241-246.

22. Dickerson RN, Rosato EF, Mullen JL. Net protein anabolism with hypocaloric parenteral nutrition in obese stressed patients. Am J Clin Nutr. 1986;44(6):747-755.

23. JC B, Goon A, PS C, Flancbaum L. Efficacy of hypocaloric total parenteral nutrition in hospitalized obese patients: a prospective, double-blind randomized trial. JPEN J Parenter Enter Nutr. 1994;18(3):203-207.

24. Choban PS, Burge JC, Scales D, Flancbaum L. Hypoenergetic nutrition support in hospitalized obese patients: a simplified method for clinical application. Am J Clin Nutr. 1997;66(3):546-550.

25. Alberda C, Gramlich L, Jones N, et al. The relationship between nutritional intake and clinical outcomes in critically ill patients: Results of an international multicenter observational study. Intensive Care Med. 2009;35(10):1728-1737.

26. Dickerson RN, Medling TL, Smith AC, et al. Hypocaloric, High-Protein Nutrition Therapy in Older vs Younger Critically Ill Patients With Obesity. JPEN J Parenter Enter Nutr. 2013;37 (3):342-351.

27. Hurt RT, Frazier TH, McClave SA, Cave MC. Pharmaconutrition for the Obese, Critically Ill Patient. JPEN J Parenter Enter Nutr. 2011;35 (5):60S-72S. 